\title{
Leadership, Planning, and Management of the 1856 Mormon Handcart Emigration
}

\author{
DON H. SMITH
}

IN 1856 two companies of Mormon emigrants traveling west on the Mormon Trail encountered blizzards in what is now Wyoming, with disastrous consequences. Some participants in the trek and commentators ever since have concluded that the Mormons' usual excellence in organization was absent in the 1856 handcart emigration operations. One writer went so far as to describe the actions of its leaders as "criminally careless." 1 A close look at the planning and implementation of the 1856 handcart emigration, however, shows the opposite of carelessness and organizational slackness.

The goal of the handcart plan was to bring out, at minimum expense, "those in Britain who have been in the church from the introduction of the Gospel on those lands; old members, many of whom have remained poor and unable to get away, or through infirmity are remaining." To execute the plan, the emigrants were instructed to "make hand-carts . . . and draw upon them [the

1. Wallace Stegner, The Gathering of Zion: The Story of the Mormon Trail (Lincoln, NE, 1964), 221-38. Brigham Young's ex-wife Ann Eliza Young, in Wife No. 19 (n.p., 1875), 208, speaks of the "meanness and heartless carelessness," related to the handcart emigration. See also Howard A. Christy, "Weather, Disaster, and Responsibility: An Essay on the Willie and Martin Handcart Story," BYU Studies 37 (1997-98), 10, 65; John Chislett "Narrative," in T. B. H. Stenhouse, The Rocky Mountain Saints: A Full and Complete History of the Mormons (New York, 1873), 313-14; John Jaques, Diary and History, in Stella Jaques Bell, Life History and Writings of John Jaques (Rexburg, ID, 1978), 99.

THE ANNALS OF IOWA 65 (Spring/Summer 2006). (C) The State Historical Society of Iowa, 2006. 
carts] the necessary supplies." 2 Brigham Young, president of the Church of Jesus Christ of Latter-day Saints (or Mormons), issued a basic cart design, together with instructions for the emigrants to build their own carts. ${ }^{3}$

The success of an undertaking of this magnitude required a revenue source and a financial plan, a need that had been partially supplied since the early 1850s by the Perpetual Emigrating Fund (PEF). This revolving support system was set up to aid the poor with moving expenses. During the 1855 emigration, the fund incurred a debt of over $\$ 60,000$ and could offer no assistance until its coffers were replenished. For the 1856 emigration season, Utah properties were offered for sale to affluent emigrants, with the funds derived from those transactions used by the PEF to support the season's emigration. One of the offered pieces of real estate was a house and lot owned by Brigham Young, with a $\$ 25,000$ price tag (about $\$ 522,000$ in 2006 dollars). ${ }^{4}$

THE IDEA for the handcart system originated with Brigham Young, but the primary responsibility for its execution was placed on the shoulders of Elders John Taylor in New York, Orson Spencer in St. Louis, and Franklin D. Richards in Liverpool. There was precedence for such cooperation between European church leaders and church authorities on the American frontier. Beginning in 1852, Richards, president of the European Mission, sent an American-born missionary from England ahead of the emigrants to purchase teams, wagons, and supplies for outfits that would transport Latter-day Saints across the Plains. To make the system more efficient, two emigration agents were sent out from Utah the next year to assist. One was stationed in New Orleans to meet the European emigrants and send them on

2. "Emigration," Millennial Star 17 (11/24/1855), 745; “Foreign Correspondence," Millennial Star 17 (12/22/1855), 813.

3. Brigham Young to John Taylor, 9/30/1855, President's Office Letter Book, 409, LDS Church Archives, Salt Lake City.

4. "Emigration," Millennial Star 17 (11/24/1855), 745-48; "Foreign Correspondence," Millennial Star 17 (12/22/1855), 749; St. Louis Luminary, 12/15/1855; The Mormon, 12/15/1855. For a short history of the PEF, see Hubert Howe Bancroft, History of Utah, 1540-1886 (San Francisco, 1889), 415-16. Brigham Young referred to the PEF's debt in his November 2, 1856, tabernacle address. See Deseret News, 11/17/1856. 
to St. Louis, where the other agent met them and sent them on to the outfitting camp. During the 1855 season, President Richards sent a member of his council, Daniel Spencer, to aid in the outfitting of that year's emigration. Erastus Snow, a member of the Quorum of Twelve Apostles and the church leader in the Midwest, took over as director of operations at Mormon Grove, Kansas. When the outfitting was completed and the emigrants had departed for Utah, Daniel Spencer returned to his office in Liverpool. Orson Spencer, Daniel's younger brother, replaced Erastus Snow in St. Louis, and John Taylor, church leader in the eastern United States, took over the reception of the Mormon emigrants, who, henceforth, would land at ports on the East Coast. New Orleans was eliminated as a port of entry due to heavy losses from cholera suffered by emigrants in 1854 and 1855.5

With Franklin Richards in Liverpool, Orson Spencer in St. Louis, and John Taylor in New York, all things appeared in order for the 1856 emigration. Unfortunately, Orson Spencer died October 15, 1855, leaving a void in the organizational structure. With Daniel Spencer, a trained outfitter, at his disposal, Richards appears to have concluded that Orson Spencer's death gave him a clear mandate to follow the same general procedures that had been used between 1852 and 1855. Furthermore, Richards interpreted Brigham Young's instruction to mean that he, as originator of the emigration, should have the major control over the operation. On the other hand, John Taylor, as the senior Apostle, felt that it was his duty to assume leadership of all emigration matters in the United States. Without communication from Salt Lake City, which was nonexistent for several winter months each year (Brigham Young did not learn about Orson Spencer's death until December 30), Taylor had only the precedence of

5. "Foreign Correspondence," Millennial Star 17 (12/22/1855), 614; "Circular," Millennial Star 18 (2/23/1856), 121-22; "Emigration of European Saints - Important Change," St. Louis Luminary, 12/2/1854; Herald of Freedom, 5/19/1855; "Elder D. Spencer's Report on his Mission to the United States," Millennial Star 17 (9/15/1855), 577-80; “Letter from Orson Spencer," St. Louis Luminary, 8/4/ 1855. Elders were sent out from Salt Lake City to staff the outfitting posts in St. Louis and New Orleans. Horace S. Eldredge, Diary, microfilm, LDS Church Archives; Orson F. Whitney, History of Utah, 4 vols. (Salt Lake City, 1892-1904), 4:247; Andrew Jenson, comp., Latter-day Saint Biographical Encyclopedia, 4 vols. (Salt Lake City, 1901-1936), 1:103, 2:284; Frederick Piercy, Route from Liverpool to Great Salt Lake Valley (Liverpool, 1855), 1-22; Deseret News, 9/5/1855. 
1855 and his own judgment to go on. Taylor's location put him in closer touch with conditions relating to the American leg of the emigration than anyone in Europe. He had a direct link with the frontiers through missionaries serving in those areas. The telegraph, limited as it was (it did not reach Salt Lake City until October 1861), provided a means by which he could rapidly communicate with the American elders in the eastern United States on important matters needing quick resolution. ${ }^{6}$

Disruptive as it could have become, the presence of both of these men in the system, each with the feeling that it was his responsibility to take charge, turned out to have some decided advantages in the long run. When Taylor learned of Orson Spencer's death, he was aware that a European emigration was planned, although he had not yet received specific instructions regarding it. He realized that the 1856 season's emigration would differ from earlier models. With two outfitting camps, about 270 miles apart, instead of one, greater organizational skills and coordination would be required. To compound the difficulties, the first camp would be located in an unfamiliar region some distance from the traditional river supply lines.

Sensing the urgency of the situation, Taylor took immediate steps to help fill the void left by Orson Spencer. He knew that a number of missionaries would soon arrive in New York City. Among them would be the American-born Andrew Cunningham. Bishop Cunningham left Utah on September 10, 1855, in charge of a group of missionaries bound for Great Britain and elsewhere. When he arrived in St. Louis, he found a letter from Taylor directing him to go to Council Bluffs to assist with the ensuing season's emigration. Cunningham arrived in Council Bluffs on December 6, where he joined James McGaw, who had been appointed chief outfitter for the Missouri River outpost. McGaw had been the captain of an 1852 Utah-bound wagon train, and during the 1855 emigration he had met the European Mormon emigrants in New Orleans, shipped them to St. Louis, and helped with the outfitting at Mormon Grove, Kansas. He

6. There had been a misunderstanding between Taylor and Richards about the duties of each party for some time. See John Taylor to Brigham Young, 7/15/ 1855 and 8/18/1856, John Taylor file, LDS Church Archives; "Death of Orson Spencer," Millennial Star 17 (12/1/1855), 762-64; Chislett “Narrative," 339-41. 
was left in charge of the Mormon Grove outpost when the last company departed for Utah. Under Taylor's direction, McGaw and Cunningham made the initial preparations for the 1856 emigration on the American side of the Atlantic. ${ }^{7}$

Taylor received details about the 1856 handcart plan in the middle of November 1855 while he was in St. Louis reorganizing the leadership after Orson Spencer's death. James H. Hart, an English emigrant, was appointed to succeed Spencer. However, he lacked the know-how to adequately fulfill all of the responsibilities of an emigration agent. Immediately, Taylor appointed a committee of seven missionaries from among those who had accompanied Cunningham from Utah to formulate plans for the structure of the carts and to calculate the supplies needed for each handcart pioneer. After Taylor received their report, he asked the Espenschied Wagon Factory based in St. Louis to build a sample cart. Then, after making some changes in the design, he ordered 100 carts from that firm. ${ }^{8}$

In accordance with instructions, Cunningham stayed only a short time in Council Bluffs, then proceeded to inspect the route from that point to Iowa City and check the progress of the railroad being built from the Mississippi River toward Iowa City. He spent Christmas in the Iowa capital and found the community in a state of excitement. Fearing that the railroad might choose some other route, the residents of Iowa City had raised $\$ 50,000$ to induce the Mississippi and Missouri Railroad to build the line to their community, but they insisted that to qualify for the prize the company's first train must arrive in the city before the end of 1855. Everyone was working at a quickened

7. Andrew Cunningham to Brigham Young, 9/21/1856, LDS Church Archives; Deseret News, 9/19/1856; The Mormon, 10/13/1855; John Taylor to Brigham Young, 7/18/1856 and 8/18/1856, John Taylor file, LDS Church Archives; Kate B. Carter, comp., Heart Throbs of the West, 12 vols. (Salt Lake City, 19391951), 12:464; James McGaw to Erastus Snow, St. Louis Luminary, 1/20/1855; Richard Ballantyne to Erastus Snow, St. Louis Luminary, 4/7/1855; Milo Andrus to Erastus Snow, St. Louis Luminary, 5/5/1855 and 5/12/1855; Orson Spencer to James Hart, St. Louis Luminary, 8/11/1855; James McGaw to James Hart, St. Louis Luminary, 11/24/1855; Andrew Jenson, Encyclopedic History of the Church of Jesus Christ of Latter-day Saints (Salt Lake City, 1941), 577; John Taylor, "Emigration," The Mormon, 4/26/1855.

8. "Hand Carts for the Plains," The Mormon, 12/1/1855; John Taylor, "Emigration," The Mormon, 4/26/1855; PEF Account Books, LDS Church Archives. 
pace in order to meet the deadline. In the midst of that flurry of activity, Cunningham looked the city over and noted what services were available there. He also located a campsite and made preliminary arrangements for its use. After completing his business, he returned to Council Bluffs. In concert with McGaw, he made arrangements for another campground in Florence, Nebraska, for ferriage across the Missouri River, and for sundry other matters. ${ }^{9}$ (The campsite was located on a small section of the 1846 Mormon encampment called Winter Quarters.) Cunningham and McGaw, together with other missionaries, were in a position to supply Taylor with prevailing prices, which were needed in Liverpool to calculate the estimated expenses for the 1856 emigration. Because of adverse weather conditions, some of the desired information did not reach England in time to aid in the European planning. ${ }^{10}$

Communication concerning the intended use of handcarts in the upcoming emigration reached Liverpool on December 9, 1855, taken there by three of the missionaries who were part of Taylor's planning committee. Steps to implement the new system could not be taken immediately because of the extensive duties required to send off Mormon emigrants aboard the John J. Boyd, which left England December 12. The handcart plan was first introduced to the British Saints in the December 22 issue of the mission publication, The Millennial Star. Brigham Young wanted all of the emigrants to head west from the Missouri River by June 1 . To meet that date the last load of emigrants would have to leave Liverpool by March 1, allowing six weeks for the journey by sailing ship, one week to travel by train from the East Coast to Iowa City, a week at Iowa City, four weeks for the trek across Iowa, and a week at Florence, Nebraska. ${ }^{11}$ With

9. "Hand Carts for the Plains," The Mormon, 12/1/1855; John Taylor, "Emigration," The Mormon, 4/26/1855; Rock Island Lines News Digest 11 (October 1952), 17.

10. Although Taylor sought the current prices of cattle, he had not received that information as of February 9, 1856, a week after the Liverpool planning meeting took place. "Emigration," The Mormon, 2/9/1856. F. D. Richards received the cost estimates from John Taylor at a later date. See "Editorial," Millennial Star 18 (2/23/1856), 123.

11. "Arrival," "Foreign Correspondence," and "Departure," Millennial Star 17 (12/22/1855), 812, 813; F. D. Richards to John Taylor, 12/14/1855, British Mission Letter Books (hereafter BMLB), LDS Church Archives; "The J. J. Boyd," 
limited information and a short lead time, about 20 missionaries assembled in Liverpool on February 1, 1856, to plan the emigration. Based on anticipated funds, they concluded that about 2,000 PEF emigrants would participate in the handcart experiment. ${ }^{12}$

BIOGRAPHIES of the handcart scheme's leaders belie claims of poor management and lack of practical experience in its execution. Daniel Spencer, who was appointed general superintendent of the operation, is a prime example. Unlike the other returning missionaries, who were relatively young, he turned 62 before the last handcart company left Iowa City. (He was born July 20, 1794, in West Stockbridge, Massachusetts.) He had been a successful merchant for a quarter-century before converting to Mormonism in 1840. After becoming a Latter-day Saint, in 1844 he was chosen mayor of Nauvoo, the Mormon settlement that was also the largest city in Illinois at that time. (Nauvoo's population exceeded 10,000 in 1844, when Chicago's was 8,000.) He served as a bishop in Winter Quarters and was captain of one of the wagon trains that entered the Salt Lake Valley in 1847. When the Salt Lake Stake was organized in 1847, he was a member of the first High Council and became stake president in 1849, an

The Mormon, 3/1/1856. Brigham Young's post-conference address, November 2, 1856, published in Deseret News, 11/17/1856, proposed the June 1 departure from the Missouri River.

12. Actually, 2,012 were shipped, about 12 died en route, 6 were born, and 2 families -11 persons - stayed in New York, leaving about 1,995 to arrive in Iowa City. Emigration details, based on the findings of the missionary planning group, were published in the Millennial Star 18 (2/23/1856). Some critics claim that no one in Iowa City knew how many emigrants were coming, but six members of the planning group were at the Iowa City camp at one time or another. To conclude that no one knew how many were coming, when Spencer and other outfitters personally helped to decide the number of participants, is quite illogical. The 20 known planners were F. D. Richards, Daniel Spencer, Cyrus Wheelock, Asa Calkin (a member of the committee appointed by John Taylor to study the handcart experiment), George D. Grant, James Ferguson, J. D. T. McAllister, William H. Kimball, Joseph A. Young, James A. Little, John Kay, Spicer W. Crandall, William Walker, Leonard I. Smith, Charles R. Dana, B. Hawkins, Thomas Williams, and Edward W. Tullidge. (This group included a son of Brigham Young, a son of Heber C. Kimball, and a brother of Jedediah M. Grant, immediate family members of each of the church's First Presidency.) Spencer, Grant, Ferguson, McAllister, Kimball, and Walker were present at the Iowa City camp at one time or another. 
office he held until his departure for England in 1852. During his sojourn in England he was the First Councilor to Franklin Richards in the European Mission Presidency. He was reappointed as stake president upon his return to Salt Lake City and occupied that office until his death in 1868. Since there was no municipal government in Salt Lake City during the early years of his tenure, his duties encompassed those of a mayor and chief judge. Even disputes among gold seekers en route to California were settled in his ecclesiastical court.

He also had significant experience preparing companies for a journey across the Plains. He had taken an active part in the preparations for the 1847 trek west and had been sent from England to help Erastus Snow outfit the 1855 emigration at Mormon Grove, Kansas. Of his contributions in that emigration assignment his brother wrote the following:

A great work has been accomplished in fitting out with teams and provisions about three thousand Saints. Imagine more than half the thousands of cattle, to be wild and unaccustomed to the yoke, and a much larger portion of the drivers as unacquainted with driving as their oxen to the yoke, the labor of supervision becomes considerable. A system of order in the distribution of provisions and cattle, and wagons, and drivers, and conductors has been arranged mostly out of the raw materials, with all the precision that attends a regular army, and all without salary or pay. . . . Brother Daniel Spencer leaves to-day for St. Louis, and thence to England, to renew his former labors in Britain, having shared in the multiplied duties of forwarding the entire emigration of Saints over the plains.

With limited resources, he used every available means to get the most for every dollar. Still, Spencer was quick to realize that he could not be all things to all people; as the need arose, he created helpful offices and placed men with leadership experience in them. As John Taylor wrote, "Bro. Spencer, who is himself a very active business man, had as efficient body of men to assist him as perhaps ever were assembled together for an object of the kind." Spencer wisely delegated tasks and allowed the appointees to work out the details. ${ }^{13}$

13. LDS Biographical Encyclopedia, 1:286-89; Whitney, History of Utah, 4:89-91; "Letter from Orson Spencer," in St. Louis Luminary, 8/11/1855; "Elder D. Spencer's Report on his Mission to the United States," Millennial Star 17 (9/15/ 


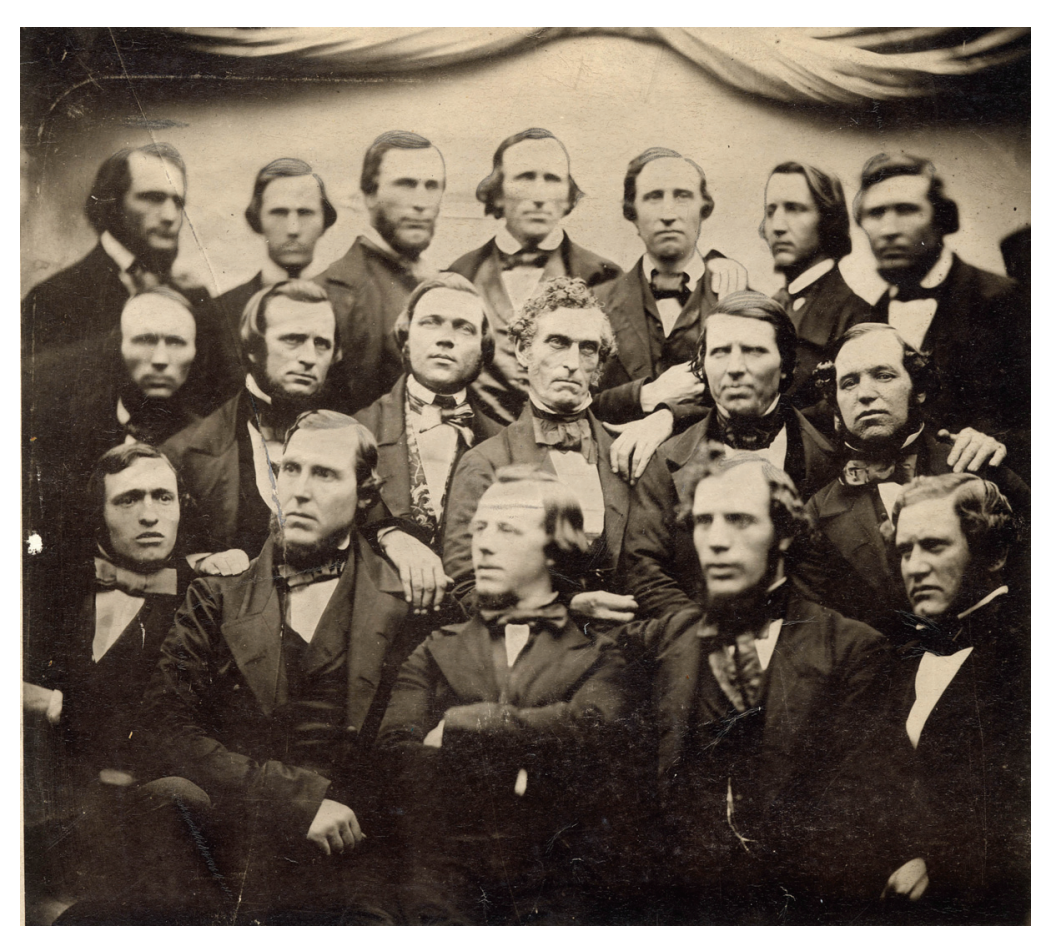

This group portrait of Mormon missionaries was taken in England in 1855. Most of these men played prominent roles in the 1856 handcart migration, including company captains Edmund Ellsworth (top left), Edward Bunker (center row left), Edward Martin (center row right), and Daniel D. McArthur (lower right). In the center row, between Bunker and Martin, are (left to right) Chauncey G. Webb, Franklin D. Richards, Daniel Spencer, and Daniel W. Jones. To Edmund Ellsworth's left in the top row are Brigham Young's son Joseph A. Young and Heber Kimball's son William H. Kimball. Photo courtesy LDS Church Archives.

The missionary captains of the last three handcart companies, all Spencer appointees, were all schooled in westward travel and were experienced leaders. They also knew the pangs of hunger and exposure to the elements. None were ignorant of

1855), 577-80; "Arrival of the Hand-Carts at Great Salt Lake City," The Mormon, 2/21/1857; William Holms Walker, Reminiscence \& Journal, in Daughters of Utah Pioneers, Lessons for January 1957, comp. Kate B. Carter (n.p., n.d.), 250-54; Stegner, Gathering of Zion, 229, 238. 
the trials awaiting them, but they were given a task to perform and they carried it out to the best of their abilities.

James G. Willie was in his forty-second year when he led his group from Iowa City. He had been born in England, but in 1836, at age 22, he emigrated to the United States. The pitfalls he endured as a lone emigrant to New York City made him street wise. After his conversion, he served several years as a missionary in New England. He traveled to Nauvoo in 1846 and then on to Winter Quarters, where he spent the winter. In 1847 he journeyed to Utah and remained there until he returned to England in 1852 as a missionary. In England he was the leader of the Southampton Pastorate before taking charge of the emigrants aboard the Thornton. Some have indicated that he led his flock on blind faith. However, he was well aware of the perils that awaited the group. On September 6-7, 1847, he had witnessed a snowstorm in the very region where many of his company were to lose their lives in October 1856 . He received a legacy of $£ 240$ upon the death of his brother and turned the money over to the PEF rather than outfit himself with a fancy horsedrawn carriage. Unlike most of the handcart leaders, he had no wagon but rode a mule that he often loaned to others. Two of his five assistants had traveled to and from Utah, and his chief adviser, the 39-year-old New Englander Millen Atwood, had made the round trip twice. ${ }^{14}$

Jesse Haven, Brigham Young's cousin, joined the Mormons in time to experience the expulsions from both Missouri and Illinois. He spent the winter at Winter Quarters and did not reach Utah until 1850 due to missionary service. In 1852 he had been called as a missionary to South Africa, where there were no Latter-day Saints. Haven led a group of three missionaries. They had no money and lived on one meal a day before they made any progress in Africa. Two of their converts purchased a ship in which a group, led by two of the missionaries, sailed to

14. James G. Willie, Missionary journals, typed copies, and Willie family history, in author's possession; Eliza R. Snow, Diary, 9/6-7/1847, in Improvement Era 47 (January 1944), 25; F. D. Richards to James G. Willie, 1/9/1856 and 5/9/1856, BMLB; James G. Willie Emigrating Company, Journal, 5/4/1856-11/9/1856, typescript, LDS Church Archives; Heart Throbs of the West, 4:243, 396; Kate B. Carter, comp., Our Pioneer Heritage, 20 vols. (Salt Lake City, 1958-1977), 2:521-22. 
London prior to emigrating aboard the Caravan. Although his company was fused with the Martin company in Florence, he, at age 42, accompanied his group most of the way to Utah in the William B. Hodgetts wagon train. ${ }^{15}$

Edward Martin is listed as the leader of the last group of emigrants to leave the Iowa City camp, but one gets the impression that the leadership was more or less a joint arrangement between Martin and Daniel Tyler. Like James Willie, Martin was English by birth but four years younger. He was one of the first Latter-day Saint converts in England and left his native land in 1841 as one of the leaders of an emigrant ship that sailed to New Orleans. He spent five years in Nauvoo before he was driven out of that city. He joined the Mormon Battalion and made the trek to California and back through Utah to Council Bluffs. The early part of his return journey began in California in July 1847 and ended in Iowa December 10. The hardships he endured during that long trek appear to have had a decided effect on his leadership style. In 1848 he returned to Utah with his family, only to leave them four years later to serve as a missionary leader in Scotland. For a short time during the 1855 emigration Martin was assigned to the emigration department in Liverpool. He was recalled to that position in 1856 to act as a passenger broker as Richards's representative with the shipping firms. Martin was the leader aboard the ship Horizon, and Haven was one of his councilors. ${ }^{16}$

Daniel Tyler was a 39-year-old native New Yorker who had gone through the refiner's fire of persecutions in Missouri, Illinois, and the Mormon Battalion. He, too, had traveled from California to Council Bluffs, but a year later than Martin. As a result of his longer stay, he was at Sutter's Fort when gold was discovered nearby. For about a year he was a missionary in England and then took over the Swiss-Italian Mission as its president. He was the leader of the Saints aboard the Caravan, assisted by Edward Bunker, William Walker, and one other

15. LDS Biographical Encyclopedia, 4:378; LDS Encyclopedic History, 808; "Emigration from South Africa," Our Pioneer Heritage, 6:272; Whitney, History of Utah, 4:512; Jesse Haven, Diary, 5/25/1856-12/15/1856, LDS Church Archives.

16. "Edward's Story," Our Pioneer Heritage, 12: 354-57; Clerks to Act as Passage Brokers, 2/6/1856, BMLB. 
who was not involved in the Iowa City operations. All ecclesiastical activities at the Iowa City camp were under his charge. ${ }^{17}$

Among other appointees, Brigham Young handpicked his son-in-law Edmund Ellsworth to be captain of the first handcart company and may have suggested other appointments. Richards made key Iowa assignments as well, which were later sustained by John Taylor, from among the missionaries who would be returning to Utah Territory. James Ferguson was assigned to act as Daniel Spencer's accountant. The wheelwright Chauncey G. Webb was to supervise construction of the handcarts. George D. Grant and William H. Kimball were to procure equipment and livestock for the emigration. ${ }^{18}$

IN THE TEN WEEKS available to them, the Mormon emigration agents in Liverpool faced many challenges: they had to convince the potential emigrants to travel by handcart, obtain cost estimates, sell the Utah real estate to British buyers and collect the funds, determine the number of qualified emigrants, arrange transportation, coordinate with the Scandinavian Mission president, and notify all those selected to emigrate. Paramount among these was raising the necessary funds in a timely manner. Although the Millennial Star announcement relating to the sale of the Utah properties and the use of the proceeds for the 1856 emigration predated the handcart directive by a month, the actual sales occurred in 1856. The majority of the funds derived from those sales came from the Thomas Tennant estate. By some means Tennant learned of the Utah property offerings prior to the Millennial Star announcement, because he wrote to Daniel Spencer on November 15, inviting Spencer to discuss emigration matters with him. Spencer and George D. Grant left immediately, arriving at Tennant's home in Hawkswick, Yorkshire, the next evening. After a short discussion, Tennant agreed to sell his property as

17. LDS Biographical Encyclopedia, 4:386, 389; Daniel Tyler, "Incidents of Experience," in Classic Experiences and Adventures (Salt Lake City, 1969), 20-46; John Daniel Thompson McAllister, Journal, 6/1/1856, microfilm, LDS Church Archives.

18. Brigham Young to Edmund Ellsworth, 9/29/1855, LDS Church Archives; "Departures," Millennial Star 18 (4/5/1856), 216-17; "Appointments," Deseret News, 6/11/1855; F. D. Richards to Daniel Spencer, 3/14/1856, BMLB; "Appointments," The Mormon, 4/12/1856. 


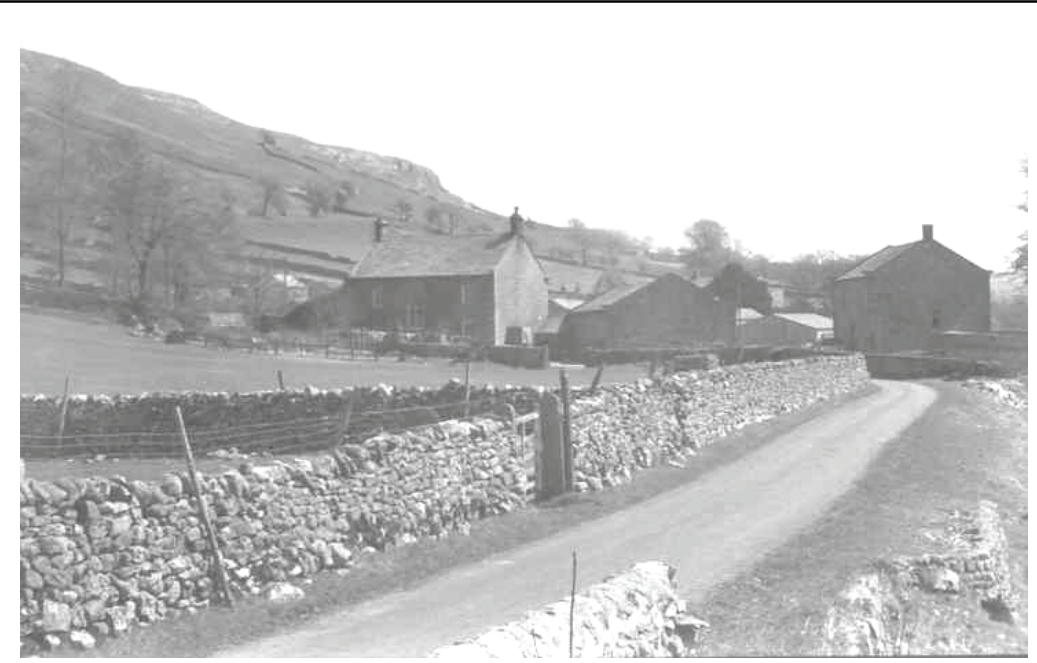

Thomas Tennant's estate in Hawkswick, Yorkshire. Courtesy of author.

soon as possible and allow President Richards to use all of the proceeds except what he needed for his family's emigration. At the same time he agreed to buy Brigham Young's \$25,000 house in Utah Territory. Spencer and Grant also met with another church member, Thomas Spencer (Tennant's nephew), who held assets worth about $£ 2,500$, or $\$ 12,100$. They tried to convince him to emigrate and to purchase one or more of the Utah property offerings, but he declined their proposition. ${ }^{19}$

It is one thing to advertise a piece of property, but quite another to sell it in a timely fashion and to obtain the desired proceeds. The sale of the Tennant estate was not consummated until April 15.20 The funds from the sale did not reach Richards until about April 24, and, much to his chagrin, part of the proceeds from the sale were in promissory notes, which reduced the amount of available funds. Eight weeks beyond the desired March 1 departure of the last shipload of emigrants slipped by before the funds from the sale of the Utah properties found

19. Daniel Spencer, Diary, 11/15-19/1855, LDS Church Archives. For comparisons of dollar values over time, see "The Inflation Calculator" at www.westegg.com/inflation.

20. Deed of sale and accounting re: the Tennant estate, in author's possession. 
their way into Richards's hands. The tardy arrival of their operating budget and the smaller than expected revenues had ripple effects on the entire handcart operation. ${ }^{21}$

War and weather also interfered with the execution of the emigration plan. The Treaty of Paris marked the end of the Crimean War on March 30, 1856. As the British soldiers began to return to England, adverse winds hindered shipping, turning the Liverpool docks into a madhouse. ${ }^{22}$ Ships were also slow to arrive in Liverpool from New York. Icebergs and storms affected traffic on the Atlantic; many ships were damaged and others sank. Sixty vessels that were due in New York City failed to show up. Some of the lowest temperatures of the century left 30 ships ice-bound in New York harbors. The average sailing time from Liverpool to New York City was about 42 days, but the Mormon emigrant ship John J. Boyd took 66 days. Another emigrant ship, the Thornton, was severely damaged during its December and January voyage from Liverpool to New York and needed extensive repairs before returning to service. It arrived back in Liverpool April 6 but could not enter the loading dock until April 17. As a result of these inconveniences its Liverpool turnaround time was 29 days. ${ }^{23}$

21. Of the approximately $\$ 50,000$ generated, Thomas Tennant contributed over $\$ 35,000$ (including the $\$ 25,000$ for Brigham Young's house). Jane Birchley contributed about \$2,430; Elias and John Jones \$440; William B. Hodgetts \$793; and James G. Willie $\$ 1,164$. Other tithing funds amounted to about $\$ 10,000$, besides PEF deposits and money paid by "ordinary" passengers. Emigrants who had excess money were encouraged to place it in the PEF as a means of transferring it to the United States. When the emigrants arrived in Utah, they could withdraw their deposits from the fund. Thus the PEF operated as a bank and the money deposited in it was available for use by the emigration agents to help defray expenses. Because of this procedure, a great deal more of the proceeds from the $\$ 60,000+$ Tennant estate, over and above the $\$ 25,000$ paid for Brigham Young's house, found its way into PEF coffers. "Editorial," Millennial Star 18 (1/12/1856), 27. The existence of promissory notes is revealed in Spencer, Diary, 2/19/1857. The evidence that these funds found their way into the hands of the mission president is in Franklin D. Richards to President of the PEF Co., 3/28/1856 and 4/25/1856, BMLB.

22. W. C. Dunbar letter from London, 3/28/1856, in Deseret News, 7/23/1856; James Linforth to F. D. Richards, 2/22/1856, BMLB; F. D. Richards to Brigham Young, 3/28/1856, BMLB; "Conclusion of Peace," The Times, 3/31/1856; Denis Judd, The Crimean War (London, 1975), 181; Liverpool Daily Post, 4/17/1856.

23. New York Tribune, 2/20/1856; New York Times, 1/15/1856, 1/21/1856, 2/7/1856, 3/10/1856, 6/23/1856; David M. Lidlum, “Early American Winters 
THE FIRST APPOINTEES to arrive in the United States from England were George D. Grant and William H. Kimball. They departed from Liverpool February 6 by steamer. Through perils of fog and icebergs they arrived in New York City 18 days later. Their arrival marked the beginning of a mammoth task that would last until all of that year's emigrants arrived in Salt Lake City nine months later. During their discussions with Taylor and his councilors, it was decided that it would be unwise for the emigrants to carry all of their tents, foodstuffs, and personal belongings on handcarts as directed. Adults were to be limited to 17 pounds of handcart baggage, with 10 pounds for children under 8 , and supply wagons were added to the plan to haul the tents, the food, and the disabled. After conferring with Taylor, Grant and Kimball went on to Iowa City to get acquainted with the area. While there, on March 20, they contracted with the Love, Gordon and Company's newly established Iowa City Plow Factory for the fabrication of 100 handcarts. Kimball went on to Council Bluffs to make final arrangements for the emigration at that point, and Grant went to Missouri to purchase equipment and check on the availability of livestock. ${ }^{24}$

Under the leadership of William H. Walker, the first 21 emigrants arrived in Iowa City about April 5. They had sailed from

II, 1821-1870," American Meteorological Society (1969), 158; "The J. J. Boyd," The Mormon, 3/1/1856; Millennial Star 18 (3/29/1856), 206; Northern Daily Times, 4/7/1856; Liverpool Telegraph E Shipping Gazette, 4/18/1856; Millennial Star 18 (5/24/1856), 230. Passage for adults was $£ 4.5$ aboard the Enoch Train and $£ 5$ aboard the Samuel Curling, with other vessels charging $£ 6$ and more, showing the increasing rates caused by adverse conditions. F. D. Richards to Dan Jones, 3/28/1856, BMLB.

24. William H. Kimball, Journal, 2/6/1856-5/20/1856, microfilm, LDS Church Archives. The first mention of the baggage weight limitation imposed on those going by handcart is found in a letter from Patience Loader in Williamsburg, New York, to her brother-in-law John Jacques in Liverpool, 4/21/1856, in "News from the United States," Millennial Star 18 (5/3/1856), 281. The letter's date and place of origin suggest that the decision was made in the New York City area before the Iowa City camp was established. The emigrants at the Iowa City camp were first apprised of the weight limitation on May 21, 1856, the day after George D. Grant and William H. Kimball arrived with a herd of cattle for the emigration. "Emigration by Hand-Carts," Millennial Star 18 (6/14/ 1856), 369-72; Daniel D. McArthur, Journal, 5/20-21/1856, LDS Church Archives; McAllister, Journal, 5/20/1856, 5/21/1856, and 5/23/1856. The order for the 100 handcarts was recorded in the Iowa Daily Republican, 3/26/1856. 
Liverpool aboard the Caravan and reached New York on March 27. No facilities had yet been prepared at Iowa City to receive these emigrants, so Walker helped find housing and employment for those who wished to work. ${ }^{25}$

Daniel Spencer, John Van Cott, Chauncey Webb, and two others left Liverpool on the steamer Canada on March 15 and landed in Boston March 30.26 On April 2, Webb left by train for Iowa City to begin preparations for handcart building; he paid $\$ 30.40$ for his ticket and arrived at his destination April 10.27 Spencer and Van Cott remained in Boston.

Spencer immediately set out to address two major challenges: arranging for the transportation of the emigrants from Boston to Iowa City, and transferring funds from Liverpool to the United States. (Such transfers were essential because not all the money needed for the season's operation was in hand when Spencer left England; neither was it wise or practical to carry on all business transactions with cash.) Spencer first called on the Enoch Train shipping firm and then left offers with railroad agents relating to emigrant rail fares. After visiting Boston's money exchanges, he concluded that it was advantageous to do business with Enoch Train and Company. With them he exchanged sovereigns for $\$ 4.85$ each and London bank notes for $\$ 4.80$. Although international banking institutions existed at that time, with branches in the larger port cities along the eastern seaboard and in Liverpool, Spencer bypassed them in favor of the better rates offered by the shipping companies. They probably offered more favorable rates in order to induce the Saints to use their ships for emigrating. ${ }^{28}$

After they completed their business in Boston, Spencer and Van Cott took the train for New York. They spent an entire day

25. "Emigrants by the Caravan and Emerald Isle," The Mormon, 4/5/1856; Walker, Reminiscence \& Journal, 250-54.

26. Spencer, Diary, 3/15-30/1856.

27. Ibid., 4/2/1856; Ann Eliza Young, Wife No. 19, 204.

28. Spencer, Diary, 3/30/1856-4/2/1856; Edward J. Perkins, Financing AngloAmerican Trade: The House of Brown, 1800-1880 (Cambridge, MA, 1975), 4-5. On a third visit to Enoch Train, Spencer obtained a bill of credit for $£ 500$ sterling $(\$ 2,425)$, for which he gave a draft on Franklin Richards. Train promised that if the draft were promptly paid he would make as many exchanges as he was called upon to execute. Spencer, Diary, 4/2/1856. 
conversing with John Taylor about the wisdom of sending the Saints across the Plains with handcarts versus wagon trains and about the differences that had arisen between the Liverpool and New York offices of the church. Taylor himself was not enthusiastic about the handcart scheme but was willing to go along with it out of respect for Brigham Young. ${ }^{29}$

Spencer received a letter addressed to him in New York from Elder Richards containing two drafts, together amounting to $£ 500(\$ 2,425)$. He was informed that James Ferguson carried with him money to pay the rail fare of the Enoch Train passengers from Boston to Iowa City at the rate of $£ 2$ (\$9.70) per adult and $£ 1$ (\$4.85) for children. Spencer received an offer from a Boston company to send adult emigrants from Boston to Iowa City for $\$ 12$ and children at half price. In search of more favorable fares, he and Taylor visited a New York railroad agent who accepted Taylor's offer of $\$ 11.50$ for adults, significantly less than the $\$ 30.40 \mathrm{Webb}$ had paid for the same journey earlier that month but still $\$ 1.80$ more for each adult and $\$ .90$ more for each child than Richards had sent from Liverpool to pay for the tickets. Spencer had to make up the difference. In subsequent negotiations he succeeded in bringing the prices down to $\$ 10$ for adults and $\$ 5$ for children by using competition as leverage. The agent also gave Spencer a free ticket to St. Louis. ${ }^{30}$

After writing letters to Franklin Richards, the Enoch Train Company, and James Ferguson (the leader of the next group of emigrants scheduled to arrive), Spencer left New York City on April 11 bound for St. Louis. He made a stop in Chicago, where he obtained bids for emigrant wagons. While preparing to leave the city, he encountered Van Cott, who, it was decided, should remain in Chicago to make further inquiries at wagon shops.

29. Spencer, Diary, 4/3-4/1856. Regarding the handcart plan, John Taylor wrote, "We do not here, however, present ourselves as its advocate; we mention the forgoing merely to show its possibility or practicability. We would not recommend them to those who have means to carry them in a more comfortable manner. We do not recognize anything very brilliant in dragging a handcart, and landing among strangers, brethren though they be, with the very limited amount of clothing and other absolute necessaries for the journey." "Hand Carts for the Plains," The Mormon, 12/1/1855.

30. Spencer, Diary, 4/4-10/1856; F. D. Richards to Daniel Spencer, 3/21/1856, BMLB; “Departures,"Millennial Star 18 (6/14/1856), 377-78. 
Spencer continued his journey to St. Louis, where he met with James Hart to coordinate emigration and business matters in that city. Later he called on the banking house of John J. Anderson, which had a history of dealings with Mormon emigration agents. There his letter of credit from Franklin Richards was discounted. Then he wrote to Richards, bringing him up to date on the latest emigration matters. When Van Cott arrived, the two elders continued business transactions with Hart. They also visited the city's wagon and carriage shops, where they compared quality and prices with those in Chicago. ${ }^{31}$

On April 19, Spencer left with Hart a draft made out in the name of Franklin Richards to be presented for execution at the John J. Anderson and Company Bank when directed by Spencer. The elders procured goods from St. Louis firms for the PEF emigrants and sent George D. Grant to purchase 15 head of oxen for the first handcart company. Then, together with Van Cott and Edward Bunker, Spencer left St. Louis for Iowa City.

FOR ALL PRACTICAL PURPOSES, Spencer's arrival in Iowa City heralded the beginning of that location's service as the staging area for the 1856 Mormon emigration. A detailed, chronological account of the activities of Spencer and his associates suggests the intricacies of the planning required for such an effort, as well as Spencer's ability to juggle a wide range of responsibilities simultaneously.

As soon as Spencer arrived, Webb briefed him on the status of the operation. Later Spencer and Van Cott visited the campground, presumably the one selected by Bishop Cunningham. Apparently they were not pleased with it, because Spencer immediately began to search for a new one. The late spring and accompanying rains made lower areas, where the first site was probably located, untenable. Construction of carts could not begin until a proper place was found for a workshop. Spencer examined the handcarts ordered by Grant and Kimball and did not like them. ${ }^{32}$

31. Spencer, Diary, 4/11-18/1856; John Van Cott, Diary, 4/16-18/1856, typescript courtesy of the Van Cott Family.

32. Spencer, Diary, 4/19-23/1856; Van Cott, Diary, 4/23/1856; instructions to George D. Grant and William H. Kimball, February 1856, BMLB. Mrs. Isaac 
On April 24, Spencer attempted to sell a $\$ 1,700$ certificate of deposit executed by John J. Anderson and Company Bank of St. Louis. Local banks refused to accept it; therefore, he was compelled to sign and send it with Van Cott, who set out that day for Chicago to purchase wagons and lumber for handcarts but was forced to return because a derailed car had stopped traffic. Meanwhile, Spencer, in a rented horse and buggy, went to Clark's Mill, which was located on the Iowa River at the edge of present-day Coralville. He entered into a contract with Ebenezer Clark for lumber to be used to fabricate handcart bodies. During the journey he kept an open eye for potential campsites. As he returned to the city, he stopped to discuss terms for the use of the upper bridge across the Iowa River. The owner, Gilman Folsom, started negotiations with an asking price of $\$ 100$, then dropped to $\$ 75$, and finally down to $\$ 50$ (these amounts are presumably seasonal or flat-rate fees). Still dissatisfied with the price, Spencer deferred the matter. Meanwhile, building materials were purchased for needed shelters and delivered to a potential campsite, and a set of joiner tools was purchased for making handcarts. Still uneasy about the campsite selection, Spencer once again rented a horse and buggy and searched for a better one. He found a site on the south side of Clear Creek, and secured permission from the owner for its use. ${ }^{33}$

Sunday, April 27, Spencer spent the day writing letters: one to Richards reporting progress, one to James Hart in St. Louis requesting the delivery of the 100 handcarts that had been ordered by John Taylor and asking him to send a telegram to instruct Grant regarding oxen and mules (this telegram was never sent because of a downed line), and one to John Taylor inform-

Dennis, a local resident, states in one place that the camp was on Dennis land near Clear Creek, then in another place indicates that it was west of the Dennis farm. "Lest We Forget," Mormon Pioneer Story, Coralville Centennial Publication (1972), 22. In 1856 frost did not leave the ground in Muscatine, Iowa, until May 1. Theodore S. Parvin, The Climate of Iowa: Embracing the Results of the Meteorological Records of the Year 1856, at Muscatine, Iowa (Muscatine, 1857), 1-9. A 53-year study shows the winter temperatures in Iowa City to be slightly cooler on average than those in Muscatine. Iowa Environmental Mesonet, Iowa State University Department of Agronomy, http://mesonet.agron.iastate.edu/plotting/ coop/climate_fe.php?station1 $=$ ia4101\&station2 $=$ ia5837\&mode $=$ c.

33. Spencer, Diary, 4/24-26/1856. 
ing him that the Mormons coming from Boston had to pay to transport their baggage across the Mississippi River. ${ }^{34}$

Early Monday morning, April 28, Webb, Bunker, and Spencer started for the campsite with a saw and joiner tools. By about 4 p.m. they had completed a granary and wagon shop. Webb was assigned to present proposals for using the lower bridge for the emigration because the owner of that facility had already agreed to a $\$ 30$ fee, whereas Gilman Folsom, the proprietor of the upper bridge, would not go below $\$ 50.35$

On April 29, Philemon C. Merrill and Alexander Robbins arrived in town. Merrill was to lead the season's first wagon train, which was assembled in Florence, Nebraska. Taylor had sent Robbins to St. Louis to purchase provisions and general supplies for the emigration and to arrange for their delivery to Florence. Spencer concurred with that assignment, knowing that Robbins had been a grocer in St. Louis before moving to Salt Lake City. Robbins also brought information about the ship Enoch Train that was soon to arrive in Boston with a load of emigrants, and he exchanged certificates of deposit with Spencer, one of which was given to Van Cott to use as he found necessary to meet expenses. Van Cott had, on a second attempt, succeeded in making the trip to Chicago and back. While there he had contracted with Peter Schuttler's wagon firm for 17 wagons. He had also ordered, perhaps from the same firm, 25 sets of buggy hubs, spokes, and fellies for use in fabricating the handcarts. ${ }^{36}$

On May 1, Spencer and Robbins left Iowa City. Robbins went to St. Louis to purchase and forward supplies, while Spencer headed for Boston to look after the affairs of the Enoch Train passengers. Van Cott was left in charge of the Iowa City operation. ${ }^{37}$

Under Van Cott's supervision, preparations for the handcart companies went forward. On May 2, Van Cott, accompanied by

34. Ibid., 4/27/1856, 5/10/1856.

35. Ibid., $4 / 28 / 1856$.

36. Ibid., 4/29-30/1856; Emigration Account Book, 8/11-18/1856; 1850 U.S. Census for St. Louis. Spencer appears to write Merrill's given name as an abbreviation for William, but that is corrected in Walker, Reminiscence, 250. The Enoch Train actually arrived at quarantine in Boston on April 30.

37. Spencer, Diary, 5/1/1856. 
Bunker and Merrill, went in search of timber for handcart hubs and ox yokes and possibly wagon tongues and reaches. About six miles up the Iowa River they found a suitable stand that would meet their demands. The following day Van Cott and Merrill laid out and staked the campground in preparation for erecting tents. 38

During the week of May 5 Van Cott moved his residence to the campground and made several three-mile trips back to town to transact business and purchase needed tools. Much of his time was spent making preparations for the arrival of the first emigrants, who were expected shortly. The Iowa City that Van Cott visited had few of the amenities needed to outfit emigrant companies. Its financial institutions had not matured sufficiently to handle the large money transactions needed for the handcart operations. They refused to accept bank notes issued by the J. J. Anderson bank of St. Louis. The three-month Mississippi River freeze-up hampered commerce and hindered supply efforts. The deadly winter also had an adverse effect on the availability and delivery of draft animals, which had to be brought in from elsewhere. Prior to the arrival of the railroad, the community had limited ability to receive the quantity of supplies a large emigration operation would need. Even when the railroad did arrive, mishaps were a daily occurrence that disrupted the railroad's scheduled runs. The railroad had been hastily put together in order to meet an imposed deadline. Although it reached Iowa City during the waning hours of December 31, 1855, it did not become operational until early 1856. The final ties and tracks were laid on frozen ground, in sub-zero weather, which had a devastating effect the following spring when the frost left the ground around May 1. As warmer weather arrived, the roadbed settled and shifted, creating the conditions for frequent accidents and making it difficult to plan and execute emigration activities efficiently. ${ }^{39}$

Adding to the uncertainties of the new railroad line was the loss of the railroad bridge that crossed the Mississippi River be-

38. Van Cott, Diary, 5/2-3/1856.

39. Ibid., 5/5/1856, 5/9-10/1856; Spencer, Diary, 4/24/1856; Parvin, Climate of Iowa, 1-9; Kimball, Journal, 4/23/1856-5/20/1856; Kansas City Enterprise, 3/24/1856; Rock Island Lines News Digest 11 (October 1952), 17. 
tween Rock Island and Davenport. The bridge was completed and carried its first train on April 21, 1856. Two weeks later, on May 6, a steamboat struck the pier upon which the pivotal span rested. The pier caught fire, destroying many vital elements of the wooden structure. It did not reopen until September 8 , much too late to assist the emigration. Therefore, none of the emigrant companies crossed the river by train, which caused costly delays. Apparently the ferry ride was an additional expense, not covered by the contracted train fare. This outage also subjected rail passengers to the inconvenience of transporting themselves and their baggage between the train depots and the ferry. All freight had to be unloaded at Rock Island, carried by wagons to the ferries, transported over the river to Davenport, delivered to that city's depot, and reloaded on rail cars bound for Iowa City. Van Cott's visit to Rock Island and Davenport suggests that the transfer of goods from one railroad to the other had to be arranged by the receiver. Those in charge of the emigration had no way of anticipating these particular problems, although they probably anticipated some difficulties because of the known frailties of railroad equipment and other imperfections. ${ }^{40}$

On May 12 Van Cott and William H. Walker journeyed from the campground to Iowa City to meet the group of passengers who had sailed from Liverpool on the Enoch Train. A mudslide blocked the track about seven miles east of the depot, forcing them to make preparations to greet the passengers at that point. There were not enough conveyances to accommodate the entire group at one time (523 were scheduled to make this leg of the journey), so Walker took half of the passengers on to the city. The remaining emigrants were forced to wait on the grass until 7 p.m.

40. Van Cott, Diary, 5/21-22/1856; Andrew Smith, Journal, 5/8-12/1856, LDS Church Archives; William Woodward, Diary, 6/1-2/1856, microfilm, Special Collections, Utah State University Library, Logan, UT; Willie Company, Journal, 6/22-23/1856; Samuel Openshaw, Diary, 7/8-11/1856, typescript, LDS Church Archives; Rock Island Lines News Digest 11 (October 1952), 16-17; "Rock Island Bridge Partly Burned," Chicago Daily Tribune, 5/7/1856. The delays for each group were as follows: the Enoch Train company arrived in Rock Island May 9 and departed Davenport May 12; the Samuel Curling company arrived in Rock Island May 31 and departed Davenport June 2; the Thornton company arrived in Rock Island June 24 and departed Davenport June 26; the Horizon company arrived in Rock Island July 8 and departed Davenport July 10-11. 
before departing. Most of the emigrants stayed overnight in the railroad depot warehouse. All the next day an honest effort was made to finish preparations at the camp, but heavy rain and accompanying mud made the task impossible, and the emigrants were forced to remain in the warehouse for another night. ${ }^{41}$

On the morning of May 14, wagons and handcarts began to convey the baggage to the campground. In spite of the elders' best efforts, the camp was not entirely ready by the time the emigrants arrived. They began to arrive at 6 p.m. and were not settled down until 11 p.m.; many were wet to the skin because of the heavy rain. The tents were not set up because tent material, which was much cheaper in England, was shipped as part of the passengers' baggage. The emigrants had cut up the material and sewn it into tents and wagon covers as they crossed the ocean. The mudslide across the tracks had delayed the arrival of the baggage, including the tents, and the heavy rains caused more delays in getting the tents to camp and erecting them. ${ }^{42}$

On May 17, Spencer returned to camp after a grueling journey during which he visited the wagon makers in Chicago, conferred with John Taylor in New York, and then went to Boston, where he helped arrange rail passage for the Enoch Train passengers. He found that sending the passengers from Boston to New York City, then by way of the Erie Railroad, was cheaper than using the direct route through Albany and Buffalo. In Boston he sold the surplus provisions from the Enoch Train, called on Mr. Train regarding exchange matters, and received offers from railroad officials to transport passengers from the Samuel Curling (offers that included free passage for all his personal rail travel). After completing his business in the East, he went to St. Louis to further coordinate emigration matters with Hart. While in St. Louis, he met with wood merchants to purchase lumber for handcarts and visited some hardware houses. 43

41. Van Cott, Diary, 5/12-13/1856; McAllister, Journal, 5/12/1856; "List of Passengers," The Mormon, 4/22/1856.

42. Van Cott, Diary, 5/14-15/1856; McAllister, Journal, 5/14-15/1856; F. D. Richards to James Ferguson, 3/21/1856, BMLB. Archer Walters's wife and daughter helped sew the tents. Archer Walters, Diary, 4/22/1856, in Improvement Era (September 1936), 39:574.

43. Spencer, Diary, 5/1-10/1856; McAllister, Journal, 5/17/1856. 
At the Iowa City camp, the PEF emigrants were organized into handcart companies on May 19; Edmund Ellsworth was called as captain of the first company and John D. T. McAllister captain of the second company. ${ }^{44}$

Van Cott went to Davenport on May 20 to arrange for freight deliveries. In the afternoon, Grant and Kimball arrived with draft animals for the early companies. At the Kansas City cattle market, they had found prices high and the supply limited. Due to the long, severe winter, the cattle were slow to reach the sales yard in marketable condition. Grant and Kimball scoured the area from Weston to Des Kalb, Missouri, looking for reasonably priced livestock that would supply the emigrants' needs. Considering the late spring and slow grass growth, their cattle arrived at the campsite about as quickly as Mother Nature would allow. 45

On May 21, Van Cott went from Davenport to Rock Island to continue arrangements for the transfer of freight from the Rock Island depot to the Davenport depot on the other side of the river. The following day he went on to Muscatine to arrange for the transfer of expected freight from riverboats to the train, and on to Iowa City. ${ }^{46}$

On May 23, with other American missionaries now in camp, Van Cott learned that he was needed to help Grant and Kimball purchase more than 1,000 additional livestock for the emigration. Part of these cattle were to be trailed to Iowa City and part to Florence, Nebraska. In addition to his assignment as captain of the second company, McAllister was also appointed commissary for the camp, and Truman Leonard was chosen to help him get the second handcart company ready for the Plains. ${ }^{47}$

On May 24, Van Cott and James Ferguson set out from the campground at about 6 a.m., the former to Missouri to purchase cattle, and the latter to Boston to help arrange affairs for the emigrants arriving on the Samuel Curling. They traveled together as far as the Muscatine junction. As the train bearing Van Cott

44. McAllister, Journal, 5/19/1856.

45. Ibid., 5/20/1856; Kimball, Journal, 3/20/1856-5/20/1856; William H. Kimball to Heber C. Kimball, 5/21/1856, in Deseret News, 7/2/1856; "The Kansas City Stock Market," Kansas City Enterprise, 4/26/1856.

46. Van Cott, Diary, 5/21-22/1856.

47. Ibid., 5/23/1856; McAllister, Journal, 5/23/1856. 
neared Muscatine, its engine and tender ran off the track. No one was injured, but all were shaken up. Van Cott traveled the last four miles into the city by railroad handcar. Meanwhile, Daniel Spencer organized the independent wagon company, with William B. Hodgetts as its captain. ${ }^{48}$

On May 25 the names of the next group of emigrants about to arrive - those who had embarked from Liverpool on the Samuel Curling-were read to those assembled at the camp. The next day a heavy thunderstorm pelted the camp for about two hours. One or two tents were blown over and many emigrants' beds were soaked. 49

On May 30 a shipment of handcarts arrived at the campground, probably from St. Louis. Although the Espenschied Wagon Factory had received the order for 100 carts in November 1855 , completion of the order appears to have been delayed. The Mississippi River freeze hampered the delivery of supplies, and the first documented payment of $\$ 700$ to the company was not made until April 21, 1856. A letter requesting delivery of the St. Louis handcarts dated April 28, 1856, probably did not reach its destination until about May 2. During his journey to Muscatine on May 22 Van Cott apparently arranged for the transfer of the carts from the riverboat to the railroad, and a payment voucher dated May 30 was issued for those 100 handcarts. The carts might have arrived at the Iowa City railroad station before May 30 but were probably assembled before they were brought to camp. To maximize available boat and railcar space, the carts and wagons were shipped disassembled. ${ }^{50}$

The presence of handcarts in the camp before May 30 suggests that carts built by Webb and his associates had begun to appear or that some of the 100 carts ordered from the Iowa City Plow Factory were delivered as they were completed. The Iowa

48. Van Cott, Diary, 5/24/1856; McAllister, Journal, 5/24/1856.

49. William Wright, McArthur Company Camp Journal, 5/25-26/1856, holograph, LDS Church Archives; McAllister, Journal, 5/26/1856. The public reading of the names of members of the next company scheduled to arrive at the camp is further evidence that the leaders at Iowa City were informed ahead of time regarding the number of Mormon emigrants who were coming.

50. "Hand Carts for the Plains," The Mormon, 12/1/1855; Spencer, Diary, 4/28/1856; Van Cott, Diary, 5/22/1856; PEF Account Books; McArthur, Journal, 5/30/1856, 6/1/1856; Walker, Reminiscence, 252. 
City Plow Factory was not primarily a wagon-making firm. When the factory received the order on March 20, it probably did not have sufficient materials on hand to tackle the entire job and could not proceed until it received the necessary lumber and other items. At that time, too, the Iowa River was still a block of ice, so the water-driven sawmill may not have been usable until it melted. Part of the supplies probably came up the Mississippi River, and it, too, was frozen solid. The company might have also needed to recruit additional skilled hands to fill this unusual order. The carts were requested at a time when the company was in most demand. It advertised itself as being available to make "all kinds of agricultural implement repairs on short notice." Spring was at hand, the season was late, and the farmers were eager to get to work; local business would undoubtedly take precedence over transient. The company received its first payment of $\$ 500$ on March 31, 1856, and may not have begun to build carts until after that date. These glitches in delivery of the handcarts account for some of the early delays. ${ }^{51}$

Only after the arrival of the May 30 vehicle order were emigrants divided up and assigned to particular carts. The next day Spencer returned to camp after another of his many required journeys. With McAllister needed more as commissary at the campground than as captain of the second handcart company, Daniel D. McArthur replaced him in the latter capacity. ${ }^{52}$

On June 2 the emigrants from the Samuel Curling arrived in Iowa City. Walker, Webb, and John Hunt welcomed them at the depot. They proceeded on to camp. Their numbers swelled the ranks in camp from about 550 to about 1,400. The newcomers were impressed with the spirit that existed in the camp. A newspaper reporter described the beehive of activity as follows:

The tents are arranged in rows, with wide streets between themthe wagons generally in rings, with the entrance at one side, and sleeping tents on the outside. . . . The present stock of cattle in camp is numerous and valuable. There are in all four hundred-

51. Kimball, Journal, 3/20/1856; “News from the United States," Millennial Star 18 (5/3/1856), 281; McAllister, Journal, 5/31/1856, 6/1/1856; Iowa City Directory $\mathcal{E}$ Advertiser for 1857; Iowa Daily Republican, 3/26/1856; PEF Account Books.

52. McArthur, Journal, 5/30/1856, 6/1/1856; McAllister, Journal, 5/31/1856, $6 / 1 / 1856$. 
and-forty-five oxen, twenty mules and a few horses. . . . There is seen, as you enter the camp, a smithery, a workshop and a store, all full of business and industry. There seems to be no disposition to shirk duty, however laborious. Women and children appear alike interested in getting all things ready for a start. . . . I have made the acquaintance of their leaders, and have found them courteous, cultivated, and, in business transactions, uncommonly 'sharp.' They converse freely with those in whom they have confidence, respecting their plans and prospects; and strangers can sometimes learn news of Mormon movements while the people in the camp itself are in blissful ignorance of their fate. ${ }^{53}$

The newcomers included several returning missionaries. With the appearance of the additional elders, it was now possible to complete the leadership staffing of the first two handcart companies. Up to that time the camp did not have enough qualified men, with prior experience in outfitting and Plains travel, to fill the leadership gaps. The late arrivals had not been sent with earlier companies because they were needed to shepherd emigrants, most of whom were from the poorer class of society and had not traveled far from their homes, and to protect them from those who would seek to prey on them. It was this type of care that gave "the Mormon ship" a reputation as "a family under strong and accepted discipline, with every provision for comfort, decorum and internal peace." 54

On June 7 the first company of handcart emigrants, the Ellsworth Company - numbering 275 people, with 56 handcarts (14 made in St. Louis and 42 in Iowa City) - took down their tents and loaded their carts and wagons to prepare for their departure.

53. McArthur, Journal, 6/2/1856; McAllister, Journal, 6/2/1856; Woodward, Diary, 6/1/1856; John Oakley, Diary (transcript), 6/1/1856, LDS Church Archives; "The Mormon Camp near Iowa City," New York Evening Post, reprinted in The Mormon, 8/2/1856.

54. Richard F. Burton, City of the Saints: Among the Mormons and across the Rocky Mountains to California (London, 1861), 296-97; McArthur, Journal, 6/3/1856; McAllister, Journal, 6/3/1856; Oakley, Diary, 6/3/1856. The assignments were as follows: John Oakley was appointed captain of the first hundred and William Butler captain of the second hundred in the Ellsworth company. Truman Leonard and Spicer Crandall were assigned to the McArthur company. Joseph France was instructed to go ahead of the companies to make all necessary arrangements regarding provisions and ferries between Iowa City and Council Bluffs. 
(Recall that Brigham Young wanted all of the emigrants to leave the Missouri River by June 1.) In the evening they moved out, amid much cheering, and journeyed a few hundred yards, then stopped and set up a new camp. This was a trial run to give the company experience and to work out kinks before actually starting the journey. Apparently only the leaders knew of this test; the rest of the emigrants thought they had bidden farewell. The company pulled out of camp for real on June 9 and traveled about 4 miles. On June 11, the second handcart company, the McArthur company - 222 emigrants with 44 handcarts (11 made in St. Louis, 30 in Iowa City and 3 at the campground) - rolled out of camp in fine spirits. It traveled 9 miles and overtook the first company. ${ }^{55}$

THE THIRD COMPANY, the Bunker company, was delayed for 12 days. All of the last four companies were delayed for the same reason: Brigham Young had instructed them to construct their own vehicles. The first two companies had been supplied with handcarts fabricated on contract (except for three made for the second company by Webb and his group). The record of payments to 19 emigrant cart builders (who were apparently compensated for their work in the form of food supplies) is revealing. Apparently, tradesmen with potential cart-making skills were sent early to help construct handcarts. Six of the 19 workers were passengers on the Enoch Train, eight came with the Samuel Curling, and the remaining four arrived with later groups. Oddly, only one of the five woodworkers, a carpenter, listed aboard the Caravan, ended up in camp. Three of the six Enoch Train woodworkers left with the second company and one with the first company. One wonders why the leaders sent any of the trained workers off before all of the carts were built. Perhaps it was because they were the best qualified to make repairs in case the experimental carts broke down en route. ${ }^{56}$

55. Oakley, Diary, 6/7/1856; Walker, Diary, in Improvement Era (October 1936), 39:636; Woodward, Diary, 6/7/1856, 6/9/1856, 6/11/1856; Walters, Diary, 636; McArthur, Journal, 6/11/1856; Twiss Bermingham, Diary, in American Legion Magazine, July 1917, 27; PEF Account Books.

56. Mormon Immigration Index, FHL \#025,691; PEF Account Books; Mormon Pioneer Overland Travel, 1856, at http://lds.org/churchhistory/library/ 


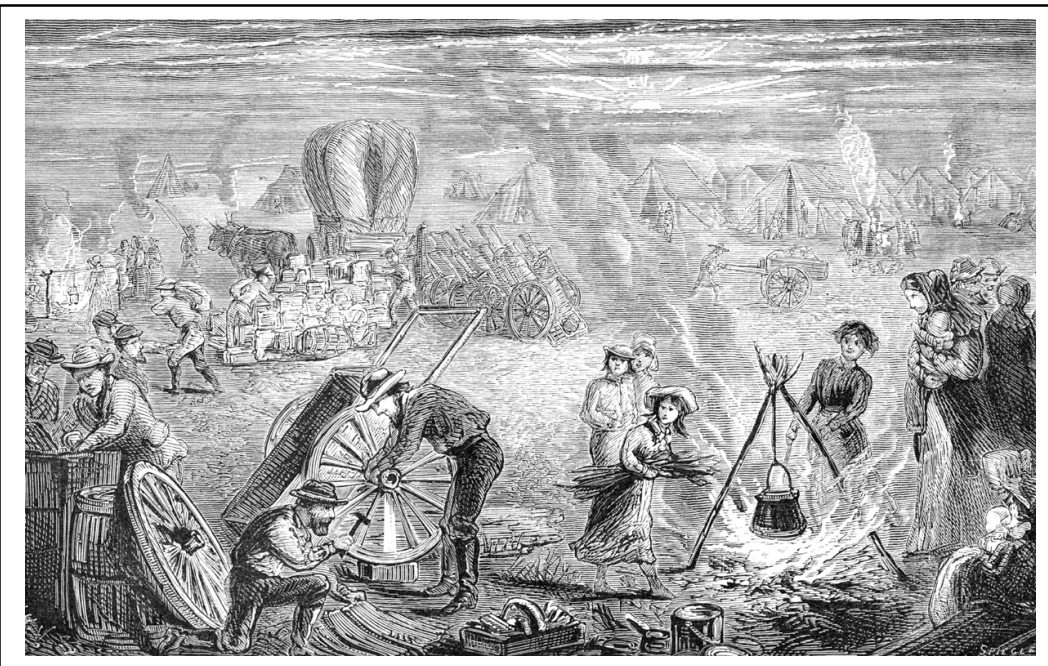

In this depiction of a handcart camp along the journey, a couple of men in the foreground work on an unloaded handcart as women and children look on. Taken from Mrs. T. B. H. Stenhouse, "Tell It All": The Story of a Life's Experience in Mormonism (Hartford, CT, 1875).

Assuming that 43 of the 58 carts required by the third company were contract carts -28 from Iowa City and 15 from St. Louis -11 of the 19 woodworkers, including the supervisor, were left to finish constructing the remaining 15. I estimate that it would have taken about nine days to build 15 carts, just about the time the third company was delayed in camp. After two workers left with the third company and one died, leaving eight to carry on until a new batch of craftsmen arrived, it is no surprise that the Willie Company had to wait 20 days, the Haven Company 16 days, and the Martin Company 20 days after their arrival in camp before departing. (Draft animals for the last three companies were delivered in a timely fashion; Van Cott brought these animals June 28 , so they could not have caused the delay. ${ }^{57}$

pioneercompanylist-chronological/0,15765,3968-1,00.html. An older wheelwright listed as part of the Caravan group appears not to have sailed, and the fate of the other wheelwright and the two wood turners is unknown.

57. In 2002 it took a wheelwright (Bill Twigg, Moscow Carriage Company, Moscow, Idaho), with modern power equipment, about six hours to construct a wheel of the type used on these carts, made with prefabricated spokes and 
It may appear that the 44 days between the building of the work facility and the departure of the first two companies was ample time to build enough carts to supply the third company's needs. But wheel making is a complex art that requires not only specialized hand tools, but also specialized workbenches, clamps, vices, jigs, anvil, and forge. A turning lathe was necessary to make the hubs, and in remote places a treadle or pole lathe was the usual tool. On the frontier such specialized tools may not have been available for purchase and often, out of necessity, had to be fabricated by the user, which took considerable time. Webb and one other may have been the only workers on hand. With the added duties that fell to Webb, he may not have found enough hours to be fully prepared for the cart-making process until after the first company arrived. Since there was only one wheelwright with the first company (he was from Switzerland and probably understood little English), a lot of training and patience were needed to get the work under way. As new workers arrived, they also needed careful instruction because they were not cart makers by trade. ${ }^{58}$

The facilities, built in a day, were crude and there were too few trained craftsmen in the emigrants' ranks for an operation of such scale. Dedicated as they may have been, they could not adequately meet each emigrant company's need for carts as it arrived. Superb leadership cannot make up for such shortages. At the time the handcart idea was first announced, frontier conditions made everyone a jack-of-all-trades. Almost every frontier household had a broad ax, an adz, a spokeshave, a hand plane, a drawknife, brace and bits, a hammer, and a crosscut saw - and knew how to use them. The 1856 Mormon handcart emigrants, however, were from a completely different envi-

fellies. Had the work been done with hand tools, he estimated that the job would have taken about 20 hours. If one were to fabricate all of the parts from raw materials, the task would have taken much longer. Using hand tools, the body and axle may have required 20 hours to construct. Assuming my estimates are correct, each cart required roughly 60 hours labor; if the builder worked 10 hours per day, he could build one cart in 6 days. Thus, it would take 90 workdays, or about 8 days per man, to construct 15 carts. With Sunday off, the time frame would be extended to 9 days. PEF Account Books; Mormon Pioneer Overland Travel, 1856; Willie Company, Journal, 6/22-23/1856.

58. PEF Account Books; Mormon Immigration Index, FHL \#025,691. 
ronment where there were fewer crossovers in occupations. (European trade guilds had a strong voice.) Tradesmen aboard the Enoch Train included a cooper, a leather cutter, a wood carver, a gun stocker, 4 carpenters, a mechanic, a turner, a cabinetmaker, 2 joiners, a shipwright, and a blacksmith. Aboard the Samuel Curling were 2 carpenters, 2 joiners, and 2 cabinetmakers. Among the 19 emigrant cart makers there were only two wheelwrights - three, if one includes the supervisor. (Anticipating the shortage, emigration leaders sent one wheelwright to camp even though he came aboard the Emerald Isle, which left Liverpool before the handcart plan arrived there.) The rest were mainly woodworkers of different types and other craftsmen. Aboard the Thornton were the following useful woodworking tradesmen: a chair maker, a shipwright, 2 Danish-speaking coopers, 2 joiners (finish carpenters), and 2 carpenters (framers), one of whom spoke no English. Of that group apparently only the 2 joiners and one carpenter spent time helping to fabricate carts. The Horizon had a wheelwright, 3 carpenters, 2 joiners, 2 cabinetmakers, a wood turner, a shipwright, a clog maker, and a blacksmith. Only one of the tradesmen who came with that ship appears on the list of workers, but that number may be understated. It seems unlikely that so few trained craftsmen could construct, from raw materials, the roughly 182 carts required by the next three companies, beyond the estimated 60 carts from St. Louis that had not yet been distributed. ${ }^{59}$

Brigham Young's instructions for constructing the handcarts included the following: "the rim should be split out of hickory like a rim to a spinning wheel only thicker, fastened and lined on the outside with green hides." Webb realized that Young's

59. Spencer, Diary, 4/24-28/1856; “TO ALL THE SAINTS IN POTTAWATAMIE,” Frontier Guardian, 11/14/1851; "Attention the Hand-cart Train," Frontier Guardian, 5/28/1852; Woodward, Diary, 6/9/1856, 6/11/1856; Walters, Diary, 636; Oakley, Diary, 6/7/1856; PEF Account Books; McArthur, Journal, 6/11/1856; Bermingham, Diary, 27; Mormon Immigration Index, FHL \#025,691. Many of the earlier details appear to have been excluded from the later account book entries because of time restraints. The number of handcarts, wagons, tents, and draft animals for each of the first four companies are detailed, but they are absent in the last companies' accounts. The leaders were so busy that even faithful journal keepers ceased to make entries during that period. Thus we lack many of the details found in earlier stages of the operation. 
directive was too time consuming and the results impractical, so he opted to use standard steam-bent fellies (rim segments) and light iron tires. ${ }^{60}$ Additional spokes and fellies were probably purchased beyond the Chicago order, and some of the drilling required for the cart fabrication was probably done off site. ${ }^{61}$ Van Cott's ability to purchase and ship buggy wheel blanks immediately upon his arrival in Chicago shows that prefabricated wheel parts were on hand in the carriage shops of that city. ${ }^{62}$ To produce the 728 fellies required for the fabrication of 364 handcart wheels would have been a daunting task, considering the number of forming jigs required and the long drying times essential for each rim section. The 4,368 spokes needed for the 364 wheels, if made by hand, would have lacked uniformity and would have required a lot of hands to produce. Thus it is unlikely that the steam-bent fellies and spokes were fabricated on site.

60. Brigham Young to John Taylor, 9/30/1855, President's Office Letter Book, 409, LDS Church Archives. We learn of Webb's alteration of the design from the only journal entry to describe the carts as they were delivered. "The handcarts which were delivered to us are well constructed and light. They have very strong wooden wheels, four feet high. The rim is made of two steam bent fellies around which is fastened an iron tire. They have wooden axles upon which are attached two shafts about eight feet long with five matching cross pieces. The carts are four feet wide and weigh 60 pounds. They provide approximately sixteen square feet for the belongings of five persons which weigh 85 pounds." Peter Madsen, Diary [translated from Danish by the author], 7/11/1856, LDS Church Archives. Unfortunately, Madsen's entry was made in Danish and has not been available to most researchers; hence, carts purporting to be authentic representations are usually built according to the original design. The carts Webb built had no box but had only a flat bed frame with canvas or bed ticking for a floor.

61. As noted above, Spencer had met with wood merchants in St. Louis in early May to purchase lumber for handcarts. Since he had already contracted with Clark's mill for the lumber to build the handcart bodies where else could this lumber be used except for the wheels? An emigration account book shows the following purchases made on June 7, 1856: iron hoop and rod, boards, drilling, nails, lumber, provisions, files, anvil and many small items. Spencer, Diary, 5/10/1856; PEF Account Books, 6/7/1856.

62. In 1819 Thomas Blanchard invented the copy lathe at the Springfield Armory. It was first used to mass produce rifle stocks but was later adapted for use in wheel-making shops to mass produce wagon and carriage wheel spokes. Thirty years later, in 1849, Blanchard invented an improved jig used to bend the rim sections (fellies) for carriage wheels, which also made it possible to mass produce those items. 
The purchased spokes and fellies were undoubtedly made of seasoned wood, and the contract for handcart-body lumber, made early in the season (April 24), ensured that material was not produced at the last minute. The idea that the handcarts were made entirely of green wood cannot be substantiated. This myth appears to have arisen from Brigham Young's design instructions directing the builders to "drive the spokes in bracing while the hub is green so it will tighten while seasoning, the same as chairs are made." Thus, green wood was used for the hubs only and was a result of design directives rather than hasty or careless construction. ${ }^{63}$ Young further proposed that the wheel hubs have leather inserts, which would serve as a bearing surface between the wooden hub and the wooden axle spindle. These instructions were, indeed, carried out; many of the carts constructed on the campground and the 100 carts fabricated in Iowa City appear to have been so made. Unfortunately, this design flaw, clearly perceived by John Taylor, was responsible for many of the cart breakdowns. Taylor remembered well the

63. Brigham Young, a chair maker by trade, had learned through training and experience that the legs and backs of chairs would remain more secure if the wooden seats were unseasoned when the chair parts were assembled. As the seat dried, it tightened around the seasoned legs and back that were inserted into holes drilled in the seat. He reasoned that a green hub, in like manner, would tighten on the spokes and make them more secure. Unfortunately, the unseasoned hub also tightened on the axle spindle and made it difficult for the wheels to turn, creating a noise that some emigrants claimed could be heard for a mile or more. To compensate for this shrinkage, a loose fit was essential, but that allowed dirt to enter the bearing surface and cut away the axle. As a result of this design flaw, axles were replaced en route to Florence; boot tops, tin sheets, and parts of cooking utensils were placed around the axles to reduce wear. When the emigrants arrived in Florence, some of the axles were replaced, and metal wear plates, made of hoop iron, were screwed on the axles to minimize the problem. The cart design instructions are in Brigham Young to John Taylor, 9/30/1855, President's Office Letter Book, 409, LDS Church Archives. Christy, "Weather, Disaster, and Responsibility," 10, 65; and Stegner, Gathering of Zion, 230, 238, suggest that the use of green wood was due to haste or carelessness. Design difficulties are described in Daniel D. McArthur to Wilford Woodruff, 1/5/1857, in Journal History, 9/26/1856, LDS Church Archives; Truman Leonard, Diary, 6/16/1856, 6/18/1856, and 7/12/1856, typescript, provided by Glen M. Leonard of LDS Museum of Church History and Art, Salt Lake City; Chislett, "Narrative," 318; Jaques, Diary and History, 119-21; Jesse Haven, Diary, 8/4/1856, microfilm, LDS Church Archives; Heart Throbs of the West (Salt Lake City, 1947), 1:84; Willie Company, Journal, 7/15/1856-8/13/ 1856; Woodward, Diary, 8/13-16/1856. 
problems created by earlier vehicles constructed in Kanesville using inadequately seasoned wood. 64

Brigham Young's 1857 handcart fabrication instructions tacitly acknowledge that there were flaws in the design of the 1856 carts and with the idea to have the emigrants fabricate their own vehicles. All of the 1857 carts were built on contract, with much stronger wheels, thick iron tires, seasoned hubs with iron sleeves, and wooden axles with iron thimbles. They also cost $\$ 6.50$ more for each cart. Apparently no fault was found in the workmanship of the carts fabricated by the Iowa City Plow Factory because the 1857 carts were ordered from that same firm. 65

THE LEADERS had done their utmost to send the companies off as soon as possible, but this emigration experiment was much more complicated than first meets the eye. When spring arrived, the country was alive with movement. Rail traffic was brisk, revenues were up, and riverboats were crowded. An estimated 2,000 people per day traveled on eastern rail lines alone $(4,000$ if southern lines are included). Antislavery forces were coming from the North and proslavery forces from the South, fomenting the crisis that would determine whether Kansas would be slave or free. One hundred thousand people were expected to arrive in Kansas alone, without numbering the thousands who were headed for western Iowa, Nebraska, and Minnesota. The arrival of these increased numbers of settlers and immigrants in areas where cattle and other supplies were generally purchased reduced the availability of essential items and

64. Spencer, Diary, 4/24/1856; Brigham Young to John Taylor, 9/30/1855; John Taylor to Brigham Young, 11/21/1855. When I tested similar wheels made with green hubs on a treadmill to verify the statements made by the emigrants, I was forced to ream the hubs 8 times in 270 miles, the distance from Iowa City to Florence, and can attest to the noise that they produced. I donated the cart and wheels, so tested, to the Church History Museum in Salt Lake City, where one can see the condition of the hubs and wheels at journey's end.

65. "Fourteenth General Epistle," Deseret News, 12/10/1856; J. M. Tanner, Biographical Sketch of James Jensen (Salt Lake City, 1911), 19-40, in William Mulder, Homeward to Zion: The Mormon Migration from Scandinavia (1957; reprint, Minneapolis, 2000), 173; James A. Little, Journal, April, May, June 1857, entry no. 1521, in Davis Bitton, Guide to Mormon Diaries and Autobiographies (Provo, UT, 1977), 215. 
increased prices, presenting an additional challenge to the emigration leaders. ${ }^{66}$

With such difficulties to face and the optimal departure time fast fading away, why didn't Spencer and other leaders, as critics have suggested, persuade the last three handcart companies and the two accompanying wagon trains to remain in the Iowa City region? Was that a viable alternative to a dangerously late departure? Among the leaders were some who had been driven from their homes in Missouri and Nauvoo, Illinois. Their previous experience had taught them that to accommodate 1,500 people and more than 400 head of draft animals would require the emigrants to be dispersed, because Johnson County's population base could not sustain such a large influx of temporary residents. After leaving Nauvoo, groups of Mormons had been forced to settle in various states. In the ten years that followed, the leaders were unable to bring them back to a central location. To spread these emigrants out would negate their goal, which was to gather the Saints and not to scatter them.

A New York Tribune reporter described contemporary conditions in the Iowa City region: "I suppose there are from five to seven thousand people here, but the casual observer would hardly suspect the number to exceed two thousand. All these Western towns are densely packed with inhabitants-houses being crowded as fast as built to their utmost capacity. . . . House rent very high." Census records verify his observations. In two year's time the population of Iowa City had more than doubled (from 2,570 in 1854 to 6,316 in 1856); Johnson County had also grown from 8,323 in 1854 to 14,457 in 1856 . The 1856 state census shows Iowa City with 982 dwellings (6.43 people per dwelling). The handcart emigrants were poor, supported by the PEF that had barely enough resources to feed them for three months. To complicate matters, many of the emigrants' food supplies lay in storage in Florence, Nebraska, or were en route to that place. The PEF did not have the means to replace the emigrants' tents with more substantial housing, and it was evident to the leaders

66. "Kansas Emigrants," Chicago Daily Tribune, 4/28/1856; "Railroad Receipts," Chicago Daily Tribune, 4/22/1856; Kimball, Journal, 4/23/1856; "To Kansas Emigrants," Chicago Daily Tribune, 3/27/1856; "Western Immigration," Chicago Daily Tribune, 4/26/1856; "Westward Ho," Chicago Daily Tribune, 4/25/1856. 
that the emigrants could not survive in tents if the previous cold winter repeated itself. (In fact, the early, heavy, enduring snows of the 1856-57 winter were, in many ways, more devastating than the extreme cold of the previous year. The populations of deer and other game animals were almost decimated. ${ }^{67}$

To remain in Iowa, the emigrants would have had to secure employment. John Taylor had established an employment placement system that was used to find job opportunities for socalled ordinary emigrants, those who had sufficient funds to pay their way to the East Coast but no further, whose names and occupations he received in advance of their arrival. Missionaries and church members in the Midwest and New England reported job openings to Taylor's New York office. As soon as arrangements could be made, he sent these ordinary emigrants to the places where there were openings for their specific occupations. The severity of the previous winter had reduced job opportunities considerably. In Cincinnati alone 10,000 people sought public relief, and conditions were similar in St. Louis and other parts of the Midwest. Three shiploads of Mormon emigrants arrived in New York between December 29, 1855, and March 27, 1856, carrying 1,319 emigrants. About 1,000 of them were of the ordinary type. They were shepherded from New York by Alexander Robbins, Taylor's councilor, who placed them in communities where he thought they could find employment. Christian Christensen met 118 Scandinavians from this group on the last day of February and escorted them across the ice-covered Mississippi to Burlington, Iowa (65 miles southeast of Iowa City). Burlington, with its 9,683 people, and surrounding Des Moines County, with a population of 20,214, were unable to absorb all of these people, forcing the remainder to go to Montrose and Keokuk to find sustenance. Another group traveled to St. Louis, where there were nine Latter-day Saint congregations to help with their maintenance, but they, too, found it difficult to secure employment. Is it reasonable to

67. “Iowa City, Feb. 3, 1857," New York Weekly Tribune, 2/28/1857; Johnson County 1854 census, Johnson County IAGenWeb site, http://iagenweb.org/ census/johnson/1854/IA-1854-IowaCity.txt; Johnson County 1856 census, State Historical Society of Iowa; PEF Account Books; David Selleck, Harrison County Iowa History (Chicago, 1891), 493-94; Covington Journal, 1/3/1857. 
believe that Johnson County could have provided winter employment and housing for 1,500 emigrants, when Des Moines County, with 5,757 more inhabitants, could not absorb 118 people? Both Robbins and Christiansen visited the emigrant camp and undoubtedly relayed their findings. ${ }^{68}$

Land speculation had reached epidemic levels, reducing employment opportunities even further. Within a ten-mile radius of Iowa City thousands of acres of rich unbroken prairie lay idle awaiting the introduction of the plow. "It seems a sorry business to grow potatoes or corn," wrote a reporter for the New York Tribune, "where men are making their thousands by buying lots one day and selling them the next at 10 to 50 percent advance. Hence, I am not surprised that vegetables are scarce in this infant city, and dearer than in New York." 69

SHORTLY AFTER HIS RETURN to Salt Lake City in the fall of 1856, Daniel Spencer summarized his accomplishments. ${ }^{70} \mathrm{He}$ had sent about 2,100 emigrants off with handcarts and 400 by wagon train; built 200 carts; made several visits to Chicago, where he had purchased 90 wagons from the Schuttler Company at a cost of about $\$ 7,000$; and purchased about 800 head of cattle, 19 mules, and 6 horses. During his several journeys he had exchanged money at the banks in Iowa City, getting $3 / 4$ percent premium for Boston paper; made several money drafts on F. D. Richards with the Enoch Train Company of Boston, the Tappscott Company of New York, and the John J. Anderson Company of St. Louis. At the latter firm he received only $\$ 4.75$ for sovereigns ( $£ 1$ gold), whereas in Boston and New York he had received $\$ 4.86$. (The differences in exchange rates for a $£ 500$

68. "To the Emigration and Our Readers Generally," The Mormon, 12/15/1855; Alexander Robbins to the Editor, Mormon, 3/15/1856; "St. Louis Stake," The Mormon, 5/3/1856; "Notice to the Saints," and "To Emigrants," The Mormon, 6/7/1856; Canute Peterson, Journal, summary of events, 2/22-3/1/1856, LDS Church Archives; Christian Christiansen, report, in Andrew Jenson, History of the Scandinavian Mission (Salt Lake City, 1927), 107; J. W. Schmidt, Oh, Du Zion $i$ Vest (Copenhagen, Denmark, 1962), 73-75; Burlington Weekly Hawk-Eye and Telegraph, 1/16/1856; Des Moines County 1856 census, Burlington Public Library.

69. “Iowa City, Feb. 3, 1857," New York Weekly Tribune, 2/28/1857.

70. Spencer, Diary, after 10/4/1856. 
bank note between St. Louis and the East Coast would buy 5.5 Iowa City-built handcarts. With free rail fares and premiums paid for Boston bank notes it is understandable why he made several trips to the East to exchange money.) During his Iowa City stay, the camp was visited by members of the legislature, Iowa's governor, and members of the Supreme Court, all of whom treated the Mormons with great respect. It would have been hard to find a more experienced and qualified leader for the task to which Spencer was assigned. Given all the challenges he faced, it is not unreasonable to assume that an experimental emigration plan, using experimental vehicles, constructed by emigrants, and starting from an unfamiliar region, with a mere ten weeks lead-time, might encounter difficulties that had little or nothing to do with failures of leadership, planning, or management. 